International Review of Research in Open and Distributed Learning Volume 19, Number 3

July -2018

\title{
Open Educational Practices in Australia: A First-phase National Audit of Higher Education
}

Adrian Stagg ${ }^{1}$, Linh Nguyen ${ }^{2}$, Carina Bossu ${ }^{3}$, Helen Partridge ${ }^{4}$, Johanna Funk ${ }^{5}$, and Kate Judith ${ }^{6}$

1,2,4,6 University of Southern Queensland, ${ }^{3}$ University of Tasmania, ${ }^{5}$ Charles Darwin University

\begin{abstract}
For fifteen years, Australian Higher Education has engaged with the openness agenda primarily through the lens of open-access research. Open educational practice (OEP), by contrast, has not been explicitly supported by federal government initiatives, funding, or policy. This has led to an environment that is disconnected, with isolated examples of good practice that have not been transferred beyond local contexts.
\end{abstract}

This paper represents first-phase research in identifying the current state of OEP in Australian Higher Education. A structured desktop audit of all Australian universities was conducted, based on a range of indicators and criteria established by a review of the literature. The audit collected evidence of engagement with OEP using publicly accessible information via institutional websites. The criteria investigated were strategies and policies, open educational resources (OER), infrastructure tools/platforms, professional development and support, collaboration/partnerships, and funding.

Initial findings suggest that the experience of OEP across the sector is diverse, but the underlying infrastructure to support the creation, (re)use, and dissemination of resources is present. Many Australian universities have experimented with, and continue to refine, massive open online course (MOOC) offerings, and there is increasing evidence that institutions now employ specialist positions to support OEP, and MOOCs. Professional development and staff initiatives require further work to build staff capacity sector-wide.

This paper provides a contemporary view of sector-wide OEP engagement in Australia-a macro-view that is not well-represented in open research to date. It identifies core areas of capacity that could be further leveraged by a national OEP initiative or by national policy on OEP.

Keywords: open educational practice, open educational resources, Australian Higher Education, Higher Education policy 


\section{Introduction}

Open educational practice (OEP) is a fast-evolving but still-emerging area of study. For the purpose of this paper, OEP is "a broad descriptor of practices that include the creation, use, and reuse of open educational resources (OER) as well as open pedagogies and open sharing of teaching practices" (Cronin, 2017, p. 2).

In Higher Education, OEP can increase access to education by lowering student costs (Conole, 2013), reducing course development costs (Conrad, Mackintosh, McGreal, Murphy, \& Witthaus, 2013), improving teaching collaboration (D’Antoni, 2008), and providing access to resources. This paper contributes to research exploring OEP in Australian Higher Education, by presenting key findings of a desktop audit covering 40 Australian universities. The paper first provides background by introducing existing literature, and OEP initiatives globally and within Australian Higher Education. This is followed by an overview of the study, data collection method and analysis, and the study's findings. The paper concludes by discussing how the findings relate to current literature, the study's practical implications, and suggestions for future research.

\section{Open Educational Practice: The Global Context}

To varying degrees of success, OEP has gained international traction. Organisations such as UNESCO have sponsored the Paris OER Declaration (UNESCO, 2012), and the earlier Cape Town Open Education Declaration (2007), which "calls on governments worldwide to openly license publicly funded educational materials for public use." Furthermore, UNESCO began global OER monitoring in 2016 (UNESCO, 2016), to understand impact of OER at the national level. The proposed UNESCO indicators explore national, state, and institutional policy responses to OEP, repository access and national-level curation, and staff engagement with OEP.

Most countries can provide local examples of OEP initiatives encompassing research and teaching funding, open textbook development, open course offerings, and repositories. In Canada, the British Columbia Ministry of Advanced Education, Innovation and Technology's Open Textbook Project, cofunded with BC Campus, provided the catalyst to develop free and open textbooks for students that are now shared globally (McGreal, Anderson, \& Conrad, 2015). Another significant move is the Memorandum of Understanding (MOU) on Open Educational Resources signed in 2012 by the three western Canadian provinces (British Columbia, Alberta, and Saskatchewan), which "includes cooperation among the provinces in sharing and developing OER; identifying, sharing and encouraging the use of OER; and by using technology, foster an understanding of OER issues” (McGreal et al., 2015, p. 168).

100 Examples of President Obama's Leadership in Science, Technology, and Innovation, notes the US federal government "invested in openly licensed education resources" (White House, 2016). The Department of Labor invested 2 billion USD to support community college OER use (White House, 2016), and the State Department released the Federal Open Licensing Playbook (2017) supporting practitioner capacity-building in open licensing, especially for federally-funded outputs.

In the UK, Scotland has progressed interinstitutional OEP collaboration, starting with the Scottish Open Education Declaration (Open Scotland Initiative, 2014) and the resulting Opening Educational Practices 
in Scotland project (OEPS, 2016). The United Kingdom cofunded JISC and the UK Higher Education Academy between 2009 and 2012 for sixty-five projects (JISC, 2013) to build capacity and develop OER for Higher Education. This is, however, an example of unsustainable practice-the funding was terminated in 2012 in the wake of sector-wide budgetary reductions and has not been reinstated.

African practitioners, by contrast, assert that "being part of the OER movement is not optional but a necessity for the African academic community" (Muganda, Samzugi, \& Mallinson, 2016 p. 38). This is driven by limited access to universities, and to ensure that African students and academic staff develop localised resources instead of passively receiving content from other countries. Most African countries lack national policy for OEP, prompting institutional approaches to support and promote OEP (Kwame Nkrumah University of Science and Technology, 2011; Africa Nazarene University, 2015).

Lastly, OEP is gathering traction in China, supported by the Chinese ministry of education (Guo, Zhang, Bonk, \& Li, 2015). This has resulted in over 20,000 open courses shared via an open source platform (xuetang online), and a focus on openly licensing Chinese research output. Despite this investment, recent research still indicates that awareness levels among Chinese Higher Education staff remain low (Guo et al., 2015).

Australian practitioners and researchers therefore have the benefit of mature OEP examples, complete with warnings about sustainability, awareness-raising, and evidence of institutional practices flourishing without explicit government funding or policy.

\section{Open Educational Practice and Australia}

OEP is still an emerging practice in Australia (Bossu \& Tynan, 2011) and whilst government departments and agencies are encouraged or mandated to adopt open principles and practices (e.g., open data, open government) the openness agenda has not yet included Higher Education despite the publically funded nature of this sector. The lack of policy levers has provided little incentive for Australian Higher Education institutions to explore OEP.

Despite this lack, Higher Education institutions have shown developing interest in OEP, demonstrated by:

- The 2014 and 2015 Australian Higher Education Horizon Reports (Johnson, Adams Becker, Estrada, \& Freeman, 2014, 2015), which forecast a "time for adoption" for OER of three to five years.

- The report recognises that awareness is the most significant challenge at the policy and practice levels.

- An increase in the number of accepted papers and presentations at Higher Education conferences in Australasia (2014 Open Education Symposium, 2015 USQ OpenSpace Conference, ASCILITE, MoodleMoot, EduTech, Apple Education Conference), which demonstrates recognition of the growing need for research-based dissemination of practice 
- A growing number of universities with supported OEP initiatives, for example OEP Learning and Teaching Grants at the University of Southern Queensland (2015-) and open professional learning Coffee Courses offered by the Australian National University (ANU)

- Universities beginning to reward and recognise OEP via their institutional academic promotion policy

- For example the University of Tasmania has this year recognised OEP in its Teaching Performance Expectations Framework, linked to evidence required for academic promotion.

- The growing number of Australian universities joining the Open Education Resources universitas (OERu) - an organisation founded to explore and offer open, accredited courses globally-and the Open Education Consortium

However, these are all single-institution activities engaging local academic staff. The overall impact of these programs, given the additional lack of interinstitutional collaboration, will be limited in the longterm, pointing to a critical need for widespread OEP support, investment, and collaboration.

The current state of OEP engagement in Australia is disconnected and neither widely understood nor adopted. This lack of awareness manifests in recent educational policy documents such as Keep It Clever, which aims to set the direction and targets for the future of universities in Australia. The document asserts Australia needs to support and enable a Higher Education sector that is "nimble, adaptive and flexible" (Universities Australia, 2016, p. 5), and identifies a need to improve accessibility, affordability, quality, and resourcing in Australian Higher Education. The connection between these goals and OEP has yet to be recognised or supported.

\section{OEP Bridging Western and Indigenous Knowledge Systems}

Australian OEP potentially addresses context-specific needs for decolonising knowledge practices and negotiating nuances in knowledge ownership. Free and open cultural licenses are a product of, and a response to, Western notions of knowledge. The Paris Declaration (UNESCO, 2012) states (Section G) the intention to:

Favour the production and use [emphasis added] of OER in local languages and diverse cultural contexts to ensure their relevance and accessibility. Intergovernmental organisations should encourage the sharing of OER across languages and cultures, respecting indigenous knowledge and rights [emphasis added] (p. 2).

Historically, respect for Indigenous Australian knowledge has been mostly absent, with a strong movement in the 1990 s to halt the appropriation of cultural works (Janke, 1999). Recent projects such as Noongarpedia (University of Western Australia \& Curtin University, 2016), the Living Archive of Aboriginal Languages (Charles Darwin University, 2012), the Ara Iritija Website (Ara Iritija Aboriginal Corporation, 1994-2016), and the Djurrwirr Project on Bowerbird (Bowerbird, 2014) seek to preserve language and cultural knowledge in appropriate ways. 
OEP maintain their distinction via emphasis on learner-led knowledge management. In Indigenous knowledge contexts, this involves well-designed practice and interaction in an already distanced and isolated environment (Funk, Guthadjaka, \& Kong, 2015; Bow, Christie, \& Devlin, 2014). Adding diverse language, cultural, ontological, and epistemological differences to the context makes the use of OEP critical for learning outcomes for a range of learners, especially marginalised ones.

Opening knowledge ownership presents an opportunity to imagine how these practices could further engage those with culturally-distinct concepts of learning in a more functional dialogue about the future of knowledge management.

\section{Criteria for the Audit: A Review of Literature}

The authors sought actionable themes of OEP-that is, criteria framing a search for sector-wide institutional evidence. Based upon a review of the literature, the criteria selected were: strategy and policy; implementation of open content; infrastructure, tools, and platforms; professional development and support; collaboration and partnerships; and funding. Each criterion was subdivided into indicators (subthemes) to nuance institutional experience or operationalisation of the criteria. The indicators are listed in "Findings," below.

\section{Strategy and Policy}

Globally, the role of government policy-makers in OEP has gained traction with the expectation that "OER will flourish when bottom-up grassroots OER development takes place in an environment supported by top-down policy" (Stacey, 2013, p. 69). Australian Higher Education is shaped primarily by government policy and target-setting; thus policy remains a strong catalyst for change.

Recent educational policy documents reflect a language of corporatisation, rationalisation focused on economic growth, and global competitiveness (Australian Government, 2016). Education is positioned as an "export," (Universities Australia, 2016, p. 23) and increasingly regarded as an individual, rather than a social, good, whilst universities "produce career-ready, globally competitive graduates to meet...21 ${ }^{\text {st }}$ century labour markets" (p. 13).

Readying students to be "wealth generators" contrasts the policy of other countries, such as the United Kingdom and Canada-countries with strong OEP adoption. The United Kingdom's "Success as a Knowledge Economy” (Department for Business, Innovation \& Skills, 2016) focuses on teaching excellence, social mobility, equitable access to education, lifelong learning, and providing student choice for education, and the economic benefits of overhauling approaches to commercialising innovation (Department for Business, Innovation \& Skills, 2016). The document "Canadian Universities and our digital future" (Universities Canada, 2016) focused on collaborative opportunities for students; the need for universities to respond to information abundance (where the value of information is no longer driven by scarcity); and user-centred approaches to education, research, and industry collaboration.

The Australian governments' focus in Higher Education has been on open research and open research data, providing transparency to taxpayer-funded research grants, and improving collaboration and competitiveness internationally. Legal expectations are embedded in research funding. The Australian 
government's Excellence Research Australia (ERA) reporting requirements have driven open repository implementations in universities, providing further evidence of the power of national policy on practice (Mamtora, Yang, \& Singh, 2015). In the context of learning and teaching, however, government policy is notably absent (Stagg \& Bossu, 2016).

\section{Implementation of Open Content}

Adopting OER within a university course poses considerable practical challenges. A review of international case studies of OER uptake in Higher Education courses (Judith \& Bull, 2016) found barriers in five major areas:

1. $\quad$ adapting material across contexts;

2. copyright issues;

3. locating context-suitable resources;

4. discoverability issues driven by diffuse nature of OER repositories; and

5. limited staff knowledge of OEP.

Although there is evidence that individual staff are adopting strategies to mitigate these challenges, unsupported individual approaches were found to have limited long-term success.

Enablers of OEP were also considered. Judith and Bull (2016) found that if long-term, systemic adoption is desired, a holistic, university-supported approach is needed. Institutional commitment to structures and processes supporting OEP offers a foundation, but tension persists between creative adaptability (an acknowledged advantage of OEP), and the perceived rigidity of institutional models.

\section{Infrastructure, Tools, and Platforms}

OEP is reliant on technological connectedness for the (co)creation, storage, and dissemination of the resources. Some of the earliest OER projects created sustainable and globally-accessible repositories (such as MERLOT, Temoa, Knowledge Without Borders, and the OER Commons). As the number of OEP projects increased, institutions constructed repositories, especially as universities (certainly in Australia) invested heavily to develop spaces to store and disseminate, first, research outcomes, and then learning objects (LO) (although it is worth noting that research repositories are usually "outward facing," whilst LO repositories are "inward facing"). The Budapest Open Access Initiative (Open Society Foundations, 2002) provided recommendations for developing and providing open access (OA) to research, namely (1) increased expectations to publish in OA journals, and (2) ensuring access to research through institutional collections.

The Australian government invested 25.5 million AUD (2005-2007) in research repositories (Mamtora et al., 2015) to address digital research storage needs. A further 16.4 million AUD (2007-2010) was allocated to develop repository reporting tools and bibliometric data harvesting systems. The number of institutional repositories rose from six in 2003, to thirty-seven (95\% of academic institutions) in 2008 
(Kennan \& Kingsley, 2009). Repositories have benefitted from not only federal government support, but also from professional bodies such as the Council for Australian University Libraries (CAUL), the Australian Library and Information Association (ALIA), and the Australian Open Access Support Group (AOASG) (Mamtora et al., 2015). Likewise, research funding organisations have begun to mandate OA to funded grant outcomes, leveraging an open access agenda for the sector.

Whilst OA research has found allies at the national level, OEP has yet to experience similar success and lacks national advocacy, policy frameworks, and incentives-perhaps indicative of a broader research/teaching divide.

\section{Professional Development and Support}

The presence of mediating artefacts-that is, any mechanism or process that makes open practice explicit to a specific audience (Conole, 2013) -is a necessary factor for OEP diffusion. They include professional learning sessions, web resources, instructional guides, human resources (such as librarians and copyright officers), and the curriculum design of programs. As OEP potentially influences changes in practice, practitioners require support to contextually integrate these new approaches (Littlejohn \& Hood, 2017).

Superficial development is insufficient to generate a commitment to change; OEP is inherently complex. Capacity development requires a "holistic process, involving the development of conceptual and practical knowledge, as well as the sociocultural knowledge and self-regulative knowledge to enable educators to make sense of and embed their learning in their contexts of practice” (Littlejohn \& Hood, 2017, p. 500). The presence of professional development and support is thus explored in this study as part of this holistic process that includes all of the previous elements, but binds them together purposefully as a sensemaking activity.

\section{Collaboration and Partnerships}

Institutional, national, and international collaboration has already been recognised as one of the many opportunities of the transformative potential of OEP (Bossu, Brown, \& Bull, 2014). It has previously been noted that the grants funded by the Office of Learning and Teaching (OLT) have not gained sector traction, nor have resources intended for reuse been adapted outside of the immediate context. This criterion sought to establish the degree to which collaboration in OEP occurred in the Australian environment, and the types of activities (if any) that these partnerships produce.

\section{Funding}

Federal government interest is indicated by the funding of a number of OEP-related grants (2010- 2014) by the OLT (disbanded by the Australian government in 2016). The project outcomes have neither been normalised nor transferred beyond their immediate context. Projects from the last decade [with funding allocation] include:

- Students, Universities, and Open Education (2014) [238,00o AUD] 
- This project explored the OEP integration with curriculum, specifically focused on MOOCs. A "national OEP roadmap" including eleven "signposts" for action was also developed (http://openedoz.org/).

- Effective open licensing policy and practice for Australian universities making online education really work (2014) [222,00o AUD]

- This project reviewed the copyright and legal issues challenging OEP in the business planning discipline (http://www.oel.edu.au/).

- A creativity skills MOOC for Australian coursework masters students (2013) [50,000 AUD]

- This project implemented and evaluated a MOOC to teach and assess creativity skills. This project developed one MOOC to be repurposed or embedded in other courses, but has yet to be reused (http://www.olt.gov.au/project-creativity-skills-mooc-australiancoursework-masters-students-2013).

- INSIGNIA: an open badge system for research training and supervision at ANU (2013) [40,000 AUD]

- INSIGNIA developed open badge strategies to support research training and supervision (http://www.olt.gov.au/project-insignia-open-badge-system-research-training-and-supervisionanu-2013).

- Bridging the gap: teaching adaptations across the disciplines and sharing content for curriculum renewal (2011) [149,243 AUD]

- This project attempted to foster resource sharing by academics teaching Adaptation Studies. The project used an institutional repository as a catalyst for sharing resources (http://www.olt.gov.au/project-bridging-gap-teaching-adaptations-across-disciplines-and-sharingcontent-curriculum-renewal-).

- Adoption, use and management of open educational resources to enhance teaching and learning in Australia (2010) [220,000 AUD]

- This project developed a feasibility protocol to enable and facilitate the adoption, use and management of open educational resources for learning and teaching within Australian Higher Education institutions (http://www.olt.gov.au/resource-adoption-use-managementopen-educational-resources).

These projects represent almost 1 million AUD of government expenditure in OEP research; expenditure that has not been backed by meaningful policy development, or even awareness of OEP at the national level. 


\section{Methods}

The research used an exploratory literature review that informed the development of the research instrument. The major themes of the review became the criteria and indicators for a structured, repeatable desktop audit of the sector. The review of literature included international research of barriers and enablers to OEP; therefore, the resulting instrument could be transferred to other contexts by researchers.

\section{Research Instrument}

An existing instrument for this research could not be located. The authors therefore developed one by reviewing OEP research (including government reports, research grant final reports, articles, conference proceedings, and "grey literature"). An initial version of the instrument was constructed and then revised by all authors. It was then used to collect data from three Australian universities. Refinement at each step ensured consistency and validity using it for the main study.

The instrument consists of six criteria, supported by indicators of the presence of activities, technology, or documentation that evidences engagement with the criteria. The six criteria are:

- Criterion 1: Strategy and policy (documentation that supports and guides the development of OEP).

- Criterion 2: Implementation of open content (the development of OERs and facilitation of access to OERs).

- Criterion 3: Infrastructure, tools, and platforms (open infrastructure that supports OEP).

- Criterion 4: Professional development, and support (opportunities for staff members develop their knowledge and skills of OEP).

- Criterion 5: Collaboration and partnerships (relationships that support OEP development).

- Criterion 6: Funding (funding for OEP research and implementation).

The review instrument would display either a 1 or a $\mathrm{o}$ to show, respectively, the presence or absence of each indicator. This would allow for an overall institutional picture to emerge. There are also spaces next to each indicator to add examples, notes, and comments (see further details in Appendix 1).

\section{Data Collection}

Data were collected during November and December 2016. In order to identify the evidence of OEP in Australian universities, a browsing and searching procedure (using a list of predetermined search termsour indicators) was implemented using search functions on Australian university websites. Major keywords such as open educational practice and open educational resources were also used to search using the Google search engine (see further details in Appendix 2). The data for each university was entered into a separate review instrument. After completion of all 40 reviews, a secondary review was 
conducted for any indicator marked with a o in the first round to identify any evidence that had been previously missed or had been recently updated by the website owner.

\section{Data Analysis}

Data from individual reviews were synthesised into a Microsoft Excel spreadsheet. A value of either 1 or 0 (i.e., "yes" or "no," respectively) was assigned to each checkpoint corresponding to each university. Notes and observations of websites sitting alongside the check boxes were also qualitatively analysed and reflected to add explanation and sophistication to the findings.

\section{Findings}

For the initial round of data collection, the indicators for each criterion were examined. As this audit sought national-level findings, the authors have chosen to display aggregate figures for the number of universities possessing the indicators, expressed as a percentage of the total number of Australian institutions. Individual institutions are only named when used as an example of practice for the indicator.

Criterion 1: Strategies and policies. Table 1 (below) presents a range of policies and strategies supporting OEP. An open-access policy was identified in 15 universities (37.5\%). An openaccess policy could either describe elements such as purpose, scope, definitions, and statement of policy (Australian National University, Charles Sturt University) or cover other details such as procedures, guidelines, and roles and responsibilities (Southern Cross University, University of New England). Only a quarter of the universities had documents such as OEP policies, strategic plans, strategic directions, or educational plans. Educational plans/strategies were the second most common form of this type of documentation in Australian universities. For example, the University of Southern Queensland's Educational Experience Plan (2015) includes an objective to "adopt organisational artefacts such as policies, procedures, guidelines, and practices that assume openness as a core principle of education" (p.4).

Table 1

OEP Strategies and Policies

\begin{tabular}{|c|c|c|c|}
\hline $\begin{array}{l}\text { Indicator } \\
\text { number }\end{array}$ & $\begin{array}{l}\text { Criterion 1: Strategies and } \\
\text { policies }\end{array}$ & $\begin{array}{l}\text { No. of universities } \\
\text { with this indicator }\end{array}$ & $\begin{array}{l}\text { Percentage of } \\
\text { universities with } \\
\text { this indicator }\end{array}$ \\
\hline 1 & Open access policies? & 15 & 37.5 \\
\hline 2 & $\begin{array}{l}\text { OER/OEP policies and } \\
\text { strategies? }\end{array}$ & 10 & 25 \\
\hline 3 & OER/OEP guidelines? & 6 & 15 \\
\hline 4 & $\begin{array}{l}\text { Innovation in educational } \\
\text { practice programs? }\end{array}$ & 5 & 12.5 \\
\hline 5 & IP rights and copyright & 4 & 10 \\
\hline
\end{tabular}




\begin{tabular}{|l|l|l|l|}
\hline & framework for OER? & & 10 \\
\hline 6 & $\begin{array}{l}\text { Open learning and teaching } \\
\text { strategy documents? }\end{array}$ & 4 & 10 \\
\hline 7 & $\begin{array}{l}\text { Recognition and reward } \\
\text { policies? }\end{array}$ & 4 & $7 \cdot 5$ \\
\hline 8 & $\begin{array}{l}\text { OER/OEP initiatives? } \\
\text { Community engagement } \\
\text { policies? }\end{array}$ & 3 & $7 \cdot 5$ \\
\hline 10 & $\begin{array}{l}\text { An open pedagogic model? } \\
\text { A vision for OER/OEP? }\end{array}$ & 2 & 5 \\
\hline 11 & $\begin{array}{l}\text { A business model promoting } \\
\text { OER/OEP? }\end{array}$ & 1 & 2.5 \\
\hline 12 & $\begin{array}{l}\text { Open learning and teaching } \\
\text { policies? }\end{array}$ & 1 & 2.5 \\
\hline 13 & Open licensing policies? & O & 2.5 \\
\hline 14 & Open assessment frameworks? & O & 0 \\
\hline 15 & $\begin{array}{l}\text { Open quality assurance } \\
\text { frameworks? }\end{array}$ & O & 0 \\
\hline 16 & (1) & & 0 \\
\hline
\end{tabular}

No Australian university had open licensing policy, open assessment, or a quality assurance framework to support OEP. Very few institutions displayed specific documentation that would support OEP such as open learning and teaching policies and business models promoting OER/OEP. The University of Tasmania is the only institution that had these two documents. Similarly, the University of Southern Queensland was the only institution to articulate a vision for open education. Its Annual Report 2016 states the university pursues a "vision to offer open and flexible Higher Education opportunities locally, nationally and internationally" (p. 2).

Criterion 2: Implementation of open content. Table 2 (below) shows the breadth of engagement with OER. Almost two thirds (26 of 40, or 65\%) of universities were using or facilitating access to OER. Universities that did provide users with a modest number of OER simply provided a list of links to the sources (Griffith University, Murdoch University), whereas other provided OER subject guides (via the library), or curated discipline-specific OER collections (Charles Darwin University, University of South Australia). 
Table 2

Implementation of Open Content in Universities

\begin{tabular}{|l|l|l|l|}
\hline $\begin{array}{l}\text { Indicator } \\
\text { number }\end{array}$ & $\begin{array}{l}\text { Criteria 2: Open educational } \\
\text { resources }\end{array}$ & $\begin{array}{l}\text { No. of universities } \\
\text { with this indicator }\end{array}$ & $\begin{array}{l}\text { Percentage of } \\
\text { universities with } \\
\text { this indicator }\end{array}$ \\
\hline $\mathbf{1 7}$ & Using/accessing OER? & 26 & 65 \\
\hline $\mathbf{1 8}$ & Open courseware and content? & 21 & 52.5 \\
\hline $\mathbf{1 9}$ & $\begin{array}{l}\text { Creating, sharing, and managing } \\
\text { OER? }\end{array}$ & $\mathbf{1 7}$ & 42.5 \\
\hline $\mathbf{2 0}$ & Free educational courses? & $\mathbf{1 1}$ & $\mathbf{2 7 . 5}$ \\
\hline $\mathbf{2 1}$ & $\begin{array}{l}\text { Open ebooks? } \\
\text { Developing/applying open } \\
\text { pedagogies? }\end{array}$ & $\mathbf{2}$ & 5 \\
\hline $\mathbf{2 2}$ & Other open learning materials? & $\mathbf{2}$ & 5 \\
\hline $\mathbf{2 3}$ & & 2 & 5 \\
\hline
\end{tabular}

Open courseware and content, was found in over a half of all universities (52.5\%), and often linked to MOOCs. Courseware and content might be of different types, such as in syllabi, lectures, course outlines, and readings, and in audio, video, textual, and graphical formats. On the contrary, it was found that three OER types, open e-books (Charles Sturt University, La Trobe University), open pedagogies, and other open learning materials (University of Southern Queensland, University of Tasmania) were the least present (5\%).

Criterion 3: Infrastructure, tools, and platforms. In relation to infrastructure, institutional repositories were used in all universities-except one-to manage learning resources, research outputs, and other work produced by students and staff. Most of these digital repositories were based on an open software program (such as Equella) or another open platform. However, most of these repositories were designed to contain closed, copyright-protected resource (such as course readings).

Table 3

Open Infrastructure, Tools, and Platforms

\begin{tabular}{|l|l|l|l|}
\hline $\begin{array}{l}\text { Indicator } \\
\text { number }\end{array}$ & $\begin{array}{l}\text { Criteria 3: Infrastructure, } \\
\text { tools, and platforms }\end{array}$ & $\begin{array}{l}\text { No. of universities } \\
\text { with this indicator }\end{array}$ & $\begin{array}{l}\text { Percentage of } \\
\text { universities with } \\
\text { this indicator }\end{array}$ \\
\hline 24 & $\begin{array}{l}\text { Institutional repositories } \\
\text { (learning materials and objects)? }\end{array}$ & 39 & 97.5 \\
\hline 25 & $\begin{array}{l}\text { Facilitating/participating in } \\
\text { MOOCs (cMOOCs, xMOOCs)? }\end{array}$ & 28 & 70 \\
\hline
\end{tabular}




\begin{tabular}{|l|l|l|l|}
\hline 26 & $\begin{array}{l}\text { Use of Web 2.o/social media (e.g. } \\
\text { wikis, blogs, social } \\
\text { networking sites, etc.) for OEP } \\
\text { related activities? }\end{array}$ & 16 & 40 \\
\hline 27 & $\begin{array}{l}\text { Tools and resources for creation } \\
\text { of OER? }\end{array}$ & 14 & 35 \\
\hline 28 & $\begin{array}{l}\text { Open software tools (e.g. learning } \\
\text { management systems)? }\end{array}$ & 12 & 30 \\
\hline 29 & $\begin{array}{l}\text { Other open tools/platforms? } \\
\text { Tools and resources being used } \\
\text { for OER/OEP? }\end{array}$ & 9 & 22.5 \\
\hline 30 & $\begin{array}{l}\text { Open content management } \\
\text { systems? }\end{array}$ & 5 & 12.5 \\
\hline 32 & $\begin{array}{l}\text { Technologies to support hosting } \\
\text { and management of OER? }\end{array}$ & 4 & 12.5 \\
\hline
\end{tabular}

Note: The term cMOOC refers to connectivist Massive Open Online Courses, and particularly the learning design employed. A cMOOC privileges learner-learner interaction, sharing, creating, and curating resources, and reflection as a tool to enhance learning. An xMOOC is more instructivist in design, and is predicated on learner-content, and learner-instructor interactions to facilitate learning experiences (McGreal, Anderson, \& Conrad, 2015)

MOOCs were offered by 28 universities (70\%). The number of MOOCs per institutions ranged from single offerings to over two dozen. MOOC platforms were also diverse, including Coursera, Open2Study, EdX, and FutureLearn; some institutions offered MOOCs on up to two or three platforms.

Universities might also use open-source software for the hosting and management of OER, content management and other open platforms. However, these technologies were used less than proprietary software packages.

Criterion 4: Professional development and support. The most common type of professional learning to support OEP were online tutorials (55\%), mainly presented as informational web page text or (less commonly) video. Organising OEP seminars/workshops to raise awareness and encourage staff engagement mainly related to Open Education Week, and Open Access Week, with little evidence of activities in the other fifty weeks of the year. 
Table 4

Professional Development and Support for OEP

\begin{tabular}{|c|c|c|c|}
\hline $\begin{array}{l}\text { Indicator } \\
\text { number }\end{array}$ & $\begin{array}{l}\text { Criteria 4: Professional } \\
\text { development and support }\end{array}$ & $\begin{array}{l}\text { No. of universities } \\
\text { with this indicator }\end{array}$ & $\begin{array}{l}\text { Percentage of } \\
\text { universities with } \\
\text { this indicator }\end{array}$ \\
\hline 33 & $\begin{array}{l}\text { Guidelines } \\
\text { and } \\
\text { tutorials } \\
\text { on } \\
\text { OER/OEP? }\end{array}$ & 22 & 55 \\
\hline 34 & $\begin{array}{l}\text { OER/OEP national and } \\
\text { international activities and } \\
\text { events? }\end{array}$ & 13 & 32.5 \\
\hline 35 & $\begin{array}{l}\text { Other supporting and } \\
\text { guidance materials? }\end{array}$ & 10 & 25 \\
\hline 36 & $\begin{array}{l}\text { OER/OEP coordinator/support } \\
\text { officer? }\end{array}$ & 8 & 20 \\
\hline 37 & $\begin{array}{l}\text { OER/OEP capacity building } \\
\text { programs? }\end{array}$ & 5 & 12.5 \\
\hline 38 & $\begin{array}{l}\text { Legal, technical and pedagogic } \\
\text { support for staff? }\end{array}$ & 3 & $7 \cdot 5$ \\
\hline 39 & Other support services? & 3 & 7.5 \\
\hline 40 & $\begin{array}{l}\text { Other professional development } \\
\text { activities for staff? }\end{array}$ & 3 & $7 \cdot 5$ \\
\hline 41 & $\begin{array}{l}\text { Support mechanisms for lecturers } \\
\text { to develop OEP? }\end{array}$ & $\mathrm{O}$ & o \\
\hline
\end{tabular}

It is noteworthy that more specific, staff-targeted support mechanisms used to foster OEP development were under-represented in the desktop audit findings. This could indicate that institutions saw it as unnecessary to openly publish information relating to support strategies, and the supporting resources. Support related to legislation (intellectual property and copyright), technical aspects (using open source technologies), and pedagogical support (OER-curriculum integration) was likewise almost absent. This is not surprising as the publicly-available register of OER-related policy and guidelines is small in Australia (POERUP, 2015). This mirrors a 10\% global increase in OER policies between 2012 and 2017 (Commonwealth on Learning, 2017). The absence of this information in a desktop audit doesn't eliminate the possibility of practice at an individual or departmental level. 
Criterion 5: Collaboration/partnerships. More than two thirds of universities (72.5\%) collaborated with at least one party to foster OEP. Some partnered with other universities, organisations, or companies to create or improve their experience of openness in education. As an illustration, Charles Sturt University partners with an industry-based education company to develop a unique series of online master's degree qualifications.

Table 5

OEP Partnerships

\begin{tabular}{|l|l|l|l|}
\hline $\begin{array}{l}\text { Indicator } \\
\text { number }\end{array}$ & $\begin{array}{l}\text { Criteria 5: Collaboration/ } \\
\text { partnerships }\end{array}$ & $\begin{array}{l}\text { No. of universities } \\
\text { with this indicator }\end{array}$ & $\begin{array}{l}\text { Percentage of } \\
\text { universities with } \\
\text { this indicator }\end{array}$ \\
\hline 42 & $\begin{array}{l}\text { Involved in any partnerships? } \\
\text { Cross institution partnerships? }\end{array}$ & 29 & 72.5 \\
\hline 43 & $\begin{array}{l}\text { Partnerships within an } \\
\text { institution? }\end{array}$ & 9 & 25 \\
\hline 44 & $\begin{array}{l}\text { National/international } \\
\text { partnerships? }\end{array}$ & 4 & 22.5 \\
\hline 45 & Other alliances? & 1 & 10 \\
\hline 46 & sol & 2.5 \\
\hline
\end{tabular}

Specifically, some universities resourced a specific team responsible for innovation in teaching and learning, which could provide technical support to faculties and teaching staff to develop courses (i.e., MOOCs). For example, the University of Wollongong (UOW) had an Open UOW team; the University of Queensland (UQ) had a UQx project team; and Charles Darwin University had an Innovative Media Production Studio.

A noticeable point is that some universities partnered with MOOC providers or open online course providers such as edX, OERu, Coursera, FutureLearn, and Open2Study. Among universities who are in building OEP partnerships, the Universities of Wollongong, Southern Queensland, and Tasmania are notable, having strong relationships with established online learning partners. However, it must be noted that engagement with MOOC platforms is not a guarantee of engagement with OEP. Whilst most MOOCs have no barriers to participation, few are developed with free and open resources, or allow free and open (re)use of this content (Czerniewicz, Deacon, Walji, \& Glover, 2017).

Criterion 6: Funding. Half of the universities provided access to funding opportunities through general schemes (i.e., schemes that are open to a wide range of disciplines and people rather than dedicated to OEP), however only 7.5\% have implemented schemes that mention OEP directly (University of Southern Queensland, Sydney University, Charles Darwin University). Those with access to general schemes allowed practitioners to apply within eligible grant areas such as innovation in learning and teaching, or curriculum transformation. 
Table 6

Sources of Funding for OEP

\begin{tabular}{|l|l|l|l|}
\hline $\begin{array}{l}\text { Indicator } \\
\text { number }\end{array}$ & Criteria 6: Funding & $\begin{array}{l}\text { No. of universities } \\
\text { with this indicator }\end{array}$ & $\begin{array}{l}\text { Percentage of } \\
\text { universities with } \\
\text { this indicator }\end{array}$ \\
\hline 47 & Other funding opportunities? & 20 & 50 \\
\hline 48 & Previous grant applications? & 6 & 15 \\
\hline 49 & Internal grants schemes? & 3 & 7.5 \\
\hline 50 & External grants schemes? & 2 & 5 \\
\hline 51 & $\begin{array}{l}\text { Institutional financial support } \\
\text { for OER/OEP? }\end{array}$ & 1 & 2.5 \\
\hline
\end{tabular}

Only one university was located that implemented an OEP-specific internal grant. Beginning as an Open Textbook Grant in 2015, these were altered in 2016 to Open Educational Practice Grants, linked to the university's vision "to offer open and flexible Higher Education opportunities locally, nationally and internationally" (University of Southern Queensland, 2016, p. 2). This type of financial support has been recognised in previous OEP research as an institutional strategy to positively recognise efforts, encourage innovation, and redesign of current learning and teaching practices (Bossu, Brown, \& Bull, 2014.

\section{Discussion of Findings}

\section{Strategies and Policies}

Given the funding environment and government levers for open access to knowledge generated in Higher Education, it is perhaps surprising that only $37.5 \%$ of institutions had a publically-accessible open-access policy. In addition, the findings did not show a clear correlation between policies and activities that universities implemented. In the second phase of this research (detailed in "Further Research Directions," below) further investigation will be undertaken to ascertain if this number is correct and if a correlation exists. What this does highlight, however, is that Australian open practice requires maturation to embrace a multi-faceted, institution-wide view of OEP. This is evidenced by a general lack of policy ( $75 \%$ of institutions with no visible policy), lack of recognition of OEP in reward and recognition (90\% of institutions do not have this), and that ninety percent of universities have no stated position on intellectual property and OEP. Furthermore, the lack of vision, business models, and targeted initiatives create an environment in which OEP struggles for a basic level of awareness among practitioners. The sector needs to recognise that all of these aspects require holistic attention that values the interrelated role of each facet in creating an inter- and intraconnected whole. Developing individual components of strategy and policy in isolation is neither sustainable nor supportive of OEP.

\section{Open Educational Resources}


Despite the lack of policy, initiatives, or reward and recognition schemes, well over half (65\%) of institutions show either use of or encouragement to access OER. The high proportion of universities (52.5\%) offering open courseware shows a desire to engage in OER, though the rationale for this activity is rarely made clear. The second-phase data collection will seek to establish nuances of practice-namely, whether OEP experiences a high level of engagement despite the lack of explicit institutional support.

Of particular interest is the centrality of the library in mediating access to OER (through library subject guides, or curated open content), which shows an opportunity for sector-wide collaboration and leadership among library and information professionals through bodies such as the Australian Library and Information Association (ALIA) and the Council of Australian University Libraries (CAUL), neither of which have statements supporting OEP. Academic librarianship is intrinsically linked to the location and evaluation of information resources for study and research; thus mediating artefacts are a simple extension of professional activities.

\section{Infrastructure}

The near-ubiquitous presence of the institutional repository (97.5\%) was unsurprising. Used to store research output and reusable learning objects, the purpose was usually focused inward on the institution to which it belonged. Seventy percent of universities had engaged with MOOCs, and $35 \%$ had tools to support the creation of OER, but only $10 \%$ had invested in technology that allowed the institution to share the resulting content. This could point to a trend of "dark reuse" (Wiley, 2009) in Australia. This refers to the anticipated behaviour wherein practitioners use OER, but do not openly share the resulting works with a broader open community (but rather share only within the institution).

Returning to the previous point about the complexity of OEP, repositories seem to be an institutional asset disconnected from overall OEP. The high level of infrastructure investment to meet government requirements for research have become popular for learning and teaching resources, and yet the same level of access and transparency are not evident. Again, this illustrates the need for a deeply connected alignment of the institution in practice and activity as part of a broader practitioner ecosystem that nurtures sector-wide OEP.

\section{Professional Development and Support}

Conole's (2013) assertion that "mediating artefacts" are required to understand, engage with, and contribute to OEP underpins both professional development and support of university staff. Some of these mediating artefacts (subject guides, curated collections) have been supplied by librarians, but these refer primarily to asynchronous, web-based resources. Human resources seem to be lacking across the sector; only $20 \%$ of universities employ staff within specific OEP roles, $12.5 \%$ have developed programs dedicated to OEP capacity-building, $7.5 \%$ have legal or pedagogic support for practitioners, and universities offering professional development activities represent only $7.5 \%$ of the sector. This low investment in human resources is perhaps indicative of the level of integration between OEP and university visions, strategies, and policies. 


\section{Collaborations/Partnerships}

Collaboration within the sector appears strong, with $72.5 \%$ of institutions maintaining partnerships with an external organisation that supports OEP, and $25 \%$ of institutions maintaining a partnership with another university that supports OEP. This does, however, illuminate a level of insularity of Australian practice, as only $10 \%$ of Higher Education institutions engage in national- or international-level partnerships that foster OEP.

\section{Finance}

In terms of internal schemes and financial support for emerging and established practitioners, only $7.5 \%$ of institutions offered internal grants that could be applied to OEP initiatives, and $2.5 \%$ provided direct financial support for OEP. Australian practitioners find greater funding opportunities outside of their institution, with $50 \%$ of universities directing staff to external bodies.

\section{Implications for Practice}

This presents a landscape in which policy and strategy are not present to support OEP, but it does also recognise examples of nascent open educational practices emerging across the sector. In this stage of Australian OEP development, it is reasonable to describe OEP progress as succeeding "through the heroic efforts of a dedicated team, rather than repeating proven methods of an organization with a mature software process" (Paulk, Curtis, Chrissis, \& Weber, 1993). This description represented some of the earliest work in understanding how isolated information and communication technologies (ICT)projects become embedded, sustainable, optimised activities, rather than ancillary systems supported only by the dedication (and often ideologically-driven goodwill) of a small cohort of staff. Whilst drawn from a different discipline, this challenge is present in efforts to mainstream OEP.

A core component to repeating proven methods is collaboration. A review of the criteria and indicators of this instrument demonstrates that evidence is drawn from a wide range of institutional stakeholders: library, ICT, academic staff, learning designers, senior managers, media producers, professional learning staff, and positions specifically dedicated to OEP. The implication, therefore, is that for OEP to become sustainable and repeatable at the institutional level, stakeholder commitment needs to be front-ended in the process. This would represent a sectoral shift from a focus on OER (the creation, storage, and dissemination of learning resources) to a culture of OEP (understanding the elements of the environment that foster openness and committing to practices that support openness as a whole-of-institution value and activity). Essentially, "[this understanding] of the concept of OEP is that it does not separate the resource from its usage, but takes into account the interplay between stakeholders, organisational elements and resources" (Ehlers \& Conole, 2010, p. 6).

Returning to Paul Stacey's earlier quote highlighting the expectation that "OER will flourish when bottom-up grassroots OER development takes place in an environment supported by top-down policy" (2013, p. 69), OEP stakeholders are perhaps in a position of both bolstering OEP activities institutionally, whilst advocating for top-down policy. Policy, however, must be approached cautiously and carefully in this environment, ensuring that grassroots autonomy inherent in OEP is not subsumed within a 
compliance-based or mandated policy structure. This balance, perhaps, represents one of the major challenges for the future of OEP.

\section{Further Research Directions}

The findings of this paper are based on a desktop audit of publically-visible evidence of engagement with OEP, which presents a specific perspective of OEP in Australian Higher Education. As the first phase of this research, the authors acknowledge that other data sources may be available but protected by institutional log-in, which raises implications for the degree to which a university subscribes to openness as an operational value. A more nuanced understanding will arise from the second phase research, during which semistructured interviews will be conducted with representatives from a sample of universities. These interviews will aim to develop contextual understanding of the data from the desktop audit and seek deeper rationale for institutional behaviours surrounding OEP. At this stage, just under 25\% of Australian universities have committed to follow-up interviews.

The questions arising from this initial review focus on whether indicators such as institutional vision, strategy, and policy are prerequisites for OEP, and to what extent OEP can flourish in environments when these documents are absent. A more integrated understanding of the larger environment in which OEP operates will be sought, as well as any practices, enablers, or barriers that are perceived as uniquely Australian. This initial phase does, however, indicate that Australian OEP in Higher Education requires further maturation before it can be viewed as widespread or sustainable.

\section{Conclusion}

OEP is still an emerging practice in Australian Higher Education. This paper presented key findings from a desktop audit seeking to establish a national picture of OEP in Australian universities. The findings presented here are the first part of a larger project and will be complemented by interviews with key stakeholders working within Australian universities. As they stand, the findings suggest that Australian universities are beginning to engage with and adopt OEP, but further maturation and cultivation at multiple levels is needed for OEP to be sustainable and to have the desired impacts. The findings reveal that more empirical research is needed to develop a richer and more nuanced understanding of openness in Australian Higher Education learning and teaching. By building a strong empirical research base we will be better placed to inform policy, practice and culture in Australian Higher Education. 


\section{References}

Africa Nazarene University. (2015). Africa Nazarene University: policy on OER integration into OdeL and campus-based provision. Retrieved from http://www.oerafrica.org/resource/africanazarene-university-policy-oer-integration-odel-and-campus-based-provision

Ara Irititja Aboriginal Corporation. (1994-2016). Anangu community archive. Retrieved from http://www.pitjantjatjaracouncil.com.au/arairititja.html

Australian Government. (2016). Driving innovation, fairness and excellence in Australian Higher Education. Canberra: Department of Education and Training. Retrieved from https://docs.education.gov.au/documents/driving-innovation-fairness-and-excellenceaustralian-education

Bossu, C., \& Tynan, B. (2011). OERs: new media on the learning landscape. On the Horizon, 19(4), 259 267. doi: 10.1108/10748121111179385.

Bossu, C., Brown, M., \& Bull, D. (2014). Adoption, use and management of Open Educational Resources to enhance teaching and learning in Australia. Sydney: Australian Government Office for Learning and Teaching. Retrieved from http://www.olt.gov.au/system/files/resources/CG10 1687 Bossu Report 2014.pdf.

Bow, C., Christie, M., \& Devlin, B. (2014). Developing a living archive of aboriginal languages. Language documentation \& conservation, 8, 345-360. http://hdl.handle.net/10125/24612

Bowerbird. (2014). Bowerbird: a place to share and discuss Australia's biodiversity. Retrieved from: http://www.BowerBird.org.au/projects/1153/sightings

Cape Town Open Education Declaration. (2007). Cape Town open education declaration: Unlocking the promise of open educational resources. Retrieved from: http://www.capetowndeclaration.org/read-the-declaration

Charles Darwin University. (2012). Living archive of Aboriginal languages. Retrieved from http://laal.cdu.edu.au/

Commonwealth of Learning. (2017) Open universities in the Commonwealth: At a glance. Retrieved from http://oasis.col.org/bitstream/handle/11599/2788/2017_COL_OER-GlobalReport.pdf?sequence $=1$ \&isAllowed $=\mathrm{y}$

Conole, G. (2013). Designing for learning in an open world. New York, United States: Springer.

Conrad, D., Mackintosh, W., McGreal, R., Murphy, A., \& Witthaus, G. (2013). Report on the assessment and accreditation of learners using OER. Retrieved from https://auspace.athabascau.ca/bitstream/handle/2149/3471/Assess-AccredOER 2013.pdf? sequence $=1$ \&isAllowed $=\mathrm{y}$ 
Cronin, C. (2017). Openness and praxis: Exploring the use of open educational practices in Higher Education. International Review of Research in Open and Distributed Learning, 18(5). http://dx.doi.org/10.19173/irrodl.v18i5.3096

Czerniewicz, L., Deacon, A., Walji, S., \& Glover, M. (2017). OER in and as MOOCs. In C. HodgkinsonWilliams \& P. B. Arinto (Eds.), Adoption and impact of OER in the Global South. Chapter 10 advance publication. http://dx.doi.org/10.5281/zenodo.161287

D'Antoni, S. (2008). Open educational resources: The way forward, deliberations of an international community of interest. Paris: UNESCO. Retrieved from http://unesdoc.unesco.org/Ulis/cgi$\underline{\text { bin/ulis.pl? catno }=157987 \& g p=1}$

Department for Business, Innovation \& Skills. (2016). Higher Education: Success as a knowledge economy - white paper. Retrieved from https://www.gov.uk/government/publications/highereducation-success-as-a-knowledge-economy-white-paper

Ehlers, U., \& Conole, G. C. (2010). Open Educational Practices: Unleashing the power of OER. UNESCO workshop on OER, Namibia. Retrieved from https://oerknowledgecloud.org/content/openeducational-practices-unleashing-power-oer

Funk, J., Guthadjaka, K., \& Kong, G. (2015). Posting traditional ecological knowledge on open access biodiversity platforms: implications for learning design. The Australian Journal of Indigenous Education, 44(2), 150-162. doi:10.1017/jie.2015.25

Guo, Y., Zhang, M., Bonk, C., Li, Y. (2015). Chinese faculty members' open educational resources (OER) usage status and the barriers to OER development and usage. International Journal of Emerging Technologies in Learning, 10(5), 59-65. doi: http://dx.doi.org/10.3991/ijet.v10i5.4819

Janke, T. (1999). Our culture: Our future. Report on Australian Indigenous cultural and intellectual property rights. Retrieved from http://www.terrijanke.com.au/our-culture-our-future

JISC. (2013). Open education. Retrieved from https://www.jisc.ac.uk/rd/projects/open-education

Johnson, L., Adams Becker, S., Estrada, V., \& Freeman, A. (2014). NMC horizon report: 2014 Higher Education edition. Austin, Texas: The New Media Consortium. Retrieved from https://www.nmc.org/publication/nmc-horizon-report-2014-higher-education-edition/

Johnson, L., Adams Becker, S., Estrada, V., \& Freeman, A. (2015). NMC horizon report: 2015 Higher Education edition. Austin, Texas: The New Media Consortium. Retrieved from https://www.nmc.org/publication/nmc-horizon-report-2015-higher-education-edition/

Judith, K., \& Bull, D. (2016). Assessing the potential for openness: a framework for examining courselevel OER implementation in higher education. Education policy analysis archives, 24(42), 1-15. doi: http://dx.doi.org/10.14507/epaa.24.1931 
Kennan, M., \& Kingsley, D. (2009). The state of the nation: A snapshot of Australian institutional repositories. First Monday, 14(2). Retrieved from http://journals.uic.edu/ojs/index.php/fm/article/view/2282

Kwame Nkrumah University of Science and Technology (KNUST). (2011). Policy for development and use of open educational resources (OER) - KNUST. Retrieved from http://www.oerafrica.org/resource/policy-development-and-use-open-educational-resourcesoer-knust

Littlejohn, A., \& Hood, N. (2017). How educators build knowledge and expand their practice: The case of open education resources. British Journal of Educational Technology, 48(2), 499-510. doi: 10.1111/bjet.12438

Mamtora, J., Yang, T., \& Singh, D. (2015). Open access repositories in the Asia-Oceania region: Experiences and guidelines from three academic institutions. International Federation of Library Associations and Institutions, 41(2), 162-176. doi: 10.1177/0340035215582219

McGreal, R., Anderson, T., \& Conrad, D. (2015). Open educational resources in Canada 2015. IRRODL, 16(5). doi: 10.19173/irrodl.v16i5.2404

Muganda, C., Samzugi, A., \& Mallinson, B. (2016). Analytical insights on the position, challenges, and potential for promoting OER in ODeL institutions in Africa. IRRODL, 17(4), 36-49. doi: http://dx.doi.org/10.19173/irrodl.v17i4.2465

OEPS. (2016). About OEPS: Open educational practices in Scotland. Retrieved from https://oepscotland.files.wordpress.com/2016/o8/oeps-flyer.pdf

Open Scotland Initiative. (2014, November 11). Scottish open education declaration 1.o. Retrieved from http://declaration.openscot.net/

Open Society Foundations. (2002). Budapest open access initiative. Retrieved from http://budapestopenaccessinitiative.org

Paulk, M., Curtis, B., Chrissis, M., \& Weber, C. (1993). Capability maturity model for software, version 1.1 (Vol. Technical report CMU/SEI-93-TR-024 ESC-TR-93-177). Pittsburgh, PA: Carnegie Mellon University.

POERUP. (2015). OER in Australia. Retrieved from http://poerup.referata.com/wiki/OER in Australia

Stacey, P. (2013). Government support for open educational resources: Policy, funding, and strategies. International Review of Research in Online and Distributed Learning, 14(2). doi: http://dx.doi.org/10.19173/irrodl.v14i2.1537

Stagg, A., \& Bossu, C. (2016). Educational policy to support the open educational practice: charting the Australian higher education landscape. In P. Blessinger \& T. Bliss (Eds.), Open education: 
international perspectives in higher education. Retrieved from http://open.uconn.edu/2017/01/05/open-education-international-perspectives-in-highereducation/

State Department. (2017). Federal open licencing playbook. Retrieved from https://eca.state.gov/files/bureau/open licensing playbook final.pdf

UNESCO. (2012). 2012 Paris OER declaration. Retrieved from http://www.unesco.org/new/en/communication-and-information/access-to-knowledge/openeducational-resources/what-is-the-paris-oer-declaration/

UNESCO. (2016). Study on international collaboration on open educational resources (OER). Retrieved from https://en.unesco.org/sites/default/files/oer_study_march_2017.pdf

Universities Australia. (2016). Keep it clever: Policy statement 2016. Retrieved from https://www.universitiesaustralia.edu.au/news/policy-papers/Keep-it-Clever--Policy-Statement2016\#.WV7UGO9E7IU

Universities Canada. (2016). Canadian universities and our digital future. Retrieved from https://www.univcan.ca/wp-content/uploads/2016/05/canadian-universities-and-our-digitalfuture-2015-workshop-report.pdf

University of Southern Queensland. (2015). Educational experience plan. Retrieved from https://www.usq.edu.au/about-usq/governance-leadership/plans-reports

University of Southern Queensland. (2016). Annual report 2016. Retrieved from https://www.usq.edu.au/-/media/USQ/About-USQ/About-us/annual-report/Final-2016Annual-Report.ashx?la=en

University of Western Australia, \& Curtin University. (2016). Noongarpedia. Retrieved from https://meta.wikimedia.org/wiki/Noongarpedia

White House. (2016). Impact report: 100 examples of President Obama's leadership in science, technology, and innovation. Office of the Press Secretary. Retrieved from https://obamawhitehouse.archives.gov/the-press-office/2016/06/21/impact-report-100examples-president-obamas-leadership-science

Wiley, D. (2009, June 10). Dark matter, dark reuse, and the irrational zeal of a believer [Web log post]. Retrieved from https://opencontent.org/blog/archives/905 


\section{Appendix 1}

\section{Audit of Open Educational Practice}

Date: November 2016

University name:

Website:

\begin{tabular}{|c|l|l|l|l|l|}
\hline No. & Categories/Check points & Yes & No & Examples/URLs & Notes/Comments \\
\hline I. & STRATEGIES \& POLICIES & & & & \\
\hline 1 & A vision for OER/OEP? & & & & \\
\hline 2 & OER/OEP policies and strategies? & & & & \\
\hline 3 & Open access policies? & & & & \\
\hline 4 & Open licensing policies? & & & & \\
\hline 5 & OER/OEP initiatives? & & & & \\
\hline 6 & Innovation in educational practice programs? & & \\
\hline 7 & OER/OEP guidelines? & & & \\
\hline 8 & IP rights and copyright framework for OER? & & & & \\
\hline 9 & A business model promoting OER/OEP? & & & & \\
\hline 10 & An open pedagogic model? & & & & \\
\hline
\end{tabular}


Open Educational Practices in Australia: A First-phase National Audit of Higher Education Stagg, Nguyen, Bossu, Partridge, Funk, and Judith

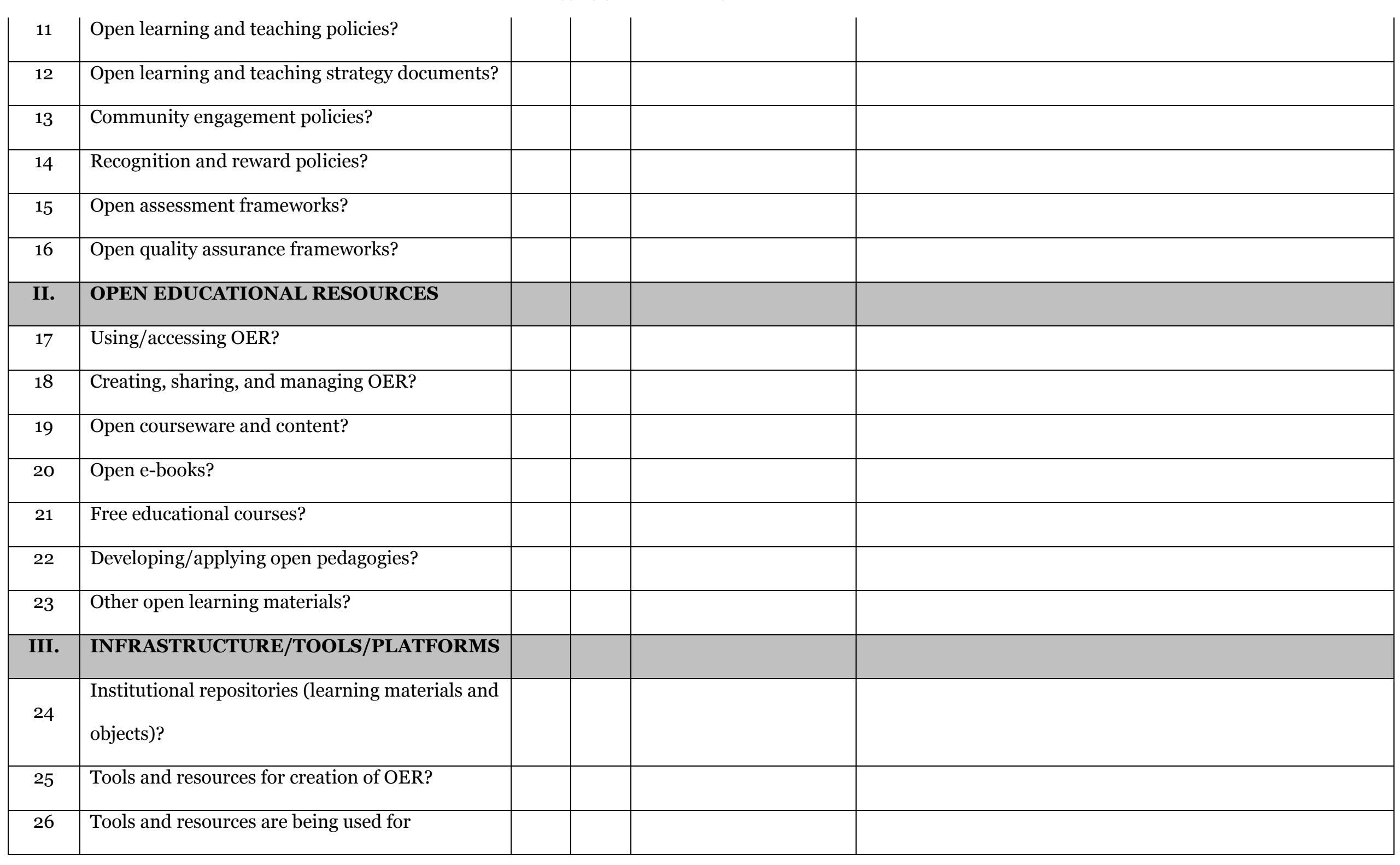


Open Educational Practices in Australia: A First-phase National Audit of Higher Education Stagg, Nguyen, Bossu, Partridge, Funk, and Judith

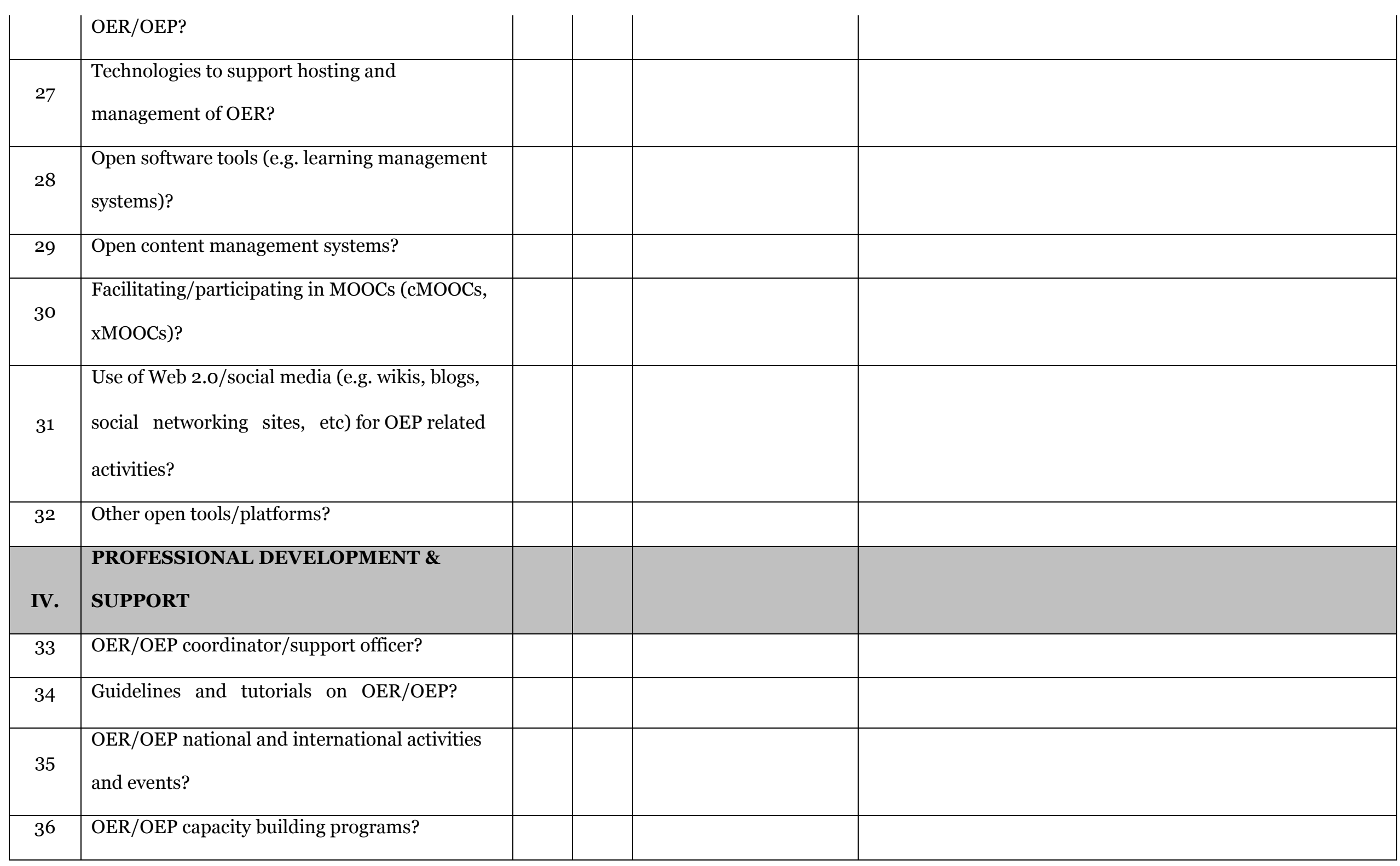


Open Educational Practices in Australia: A First-phase National Audit of Higher Education Stagg, Nguyen, Bossu, Partridge, Funk, and Judith

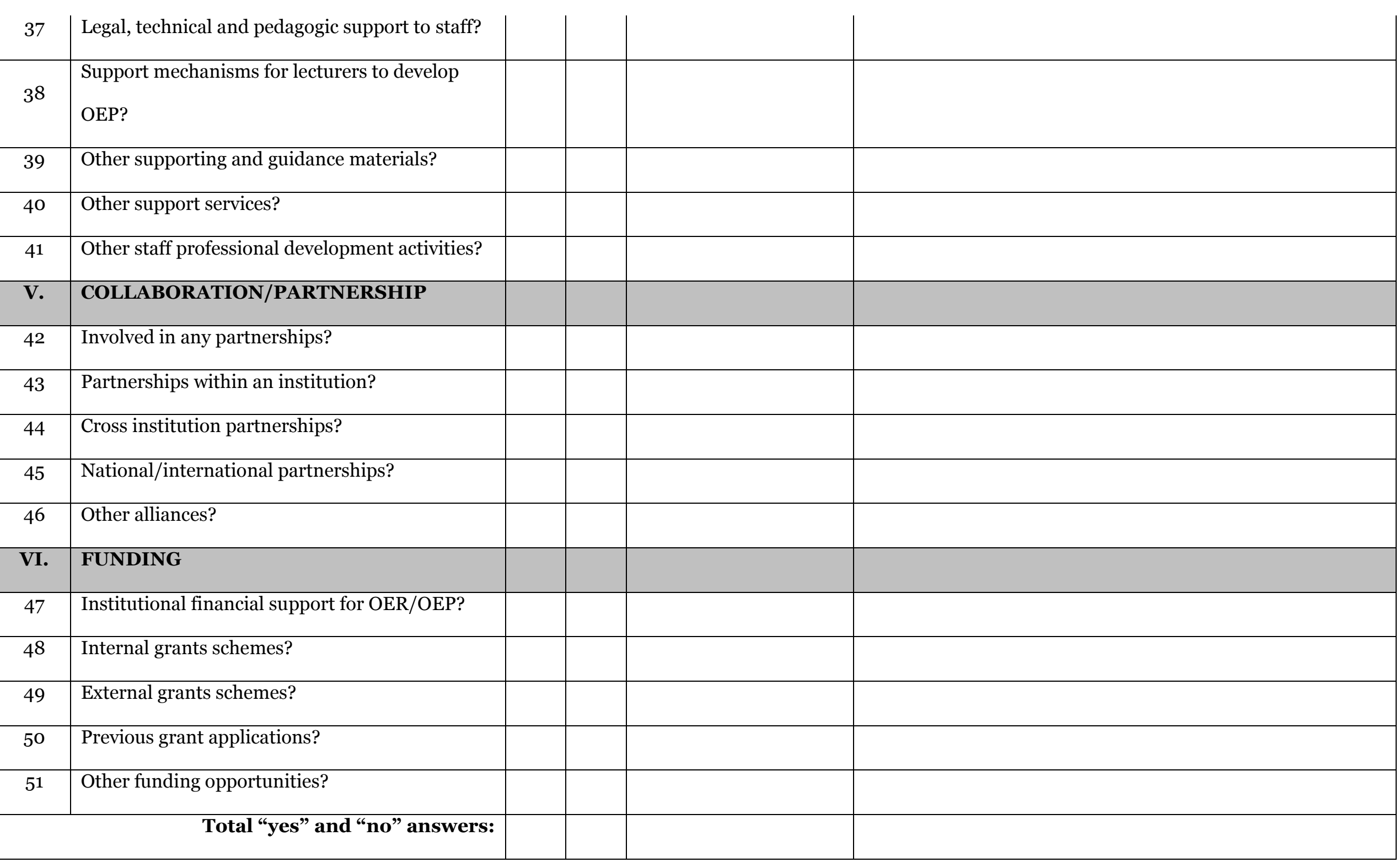


Open Educational Practices in Australia: A First-phase National Audit of Higher Education

Stagg, Nguyen, Bossu, Partridge, Funk, and Judith

\section{Appendix 2}

\section{List of Search Terms (OER/OEP Audit)}

Annual report

Blended learning

Collaborations

Community development

Community engagement

Community outreach

Content management systems

Curriculum development

Distance education

Distance learning

Funding

Grants

Guidelines

Innovation 
Institutional repository

Intellectual property rights

International cooperation

Learning design

Learning management systems

Licencing

Mobile technology

MOOCs

OEP

OER

Open access policies

Open content

Open education

Open educational practices

Open educational resources

Open licencing policies

Open practice 
Open Educational Practices in Australia: A First-phase National Audit of Higher Education

Stagg, Nguyen, Bossu, Partridge, Funk, and Judith

Open technologies

Openness

Participatory technologies

Partnerships

Policy

Professional development

Social inclusion

Strategic plan

Strategies

Textbooks

Vision

Athabasca

University

(ㅇ) (1) 